
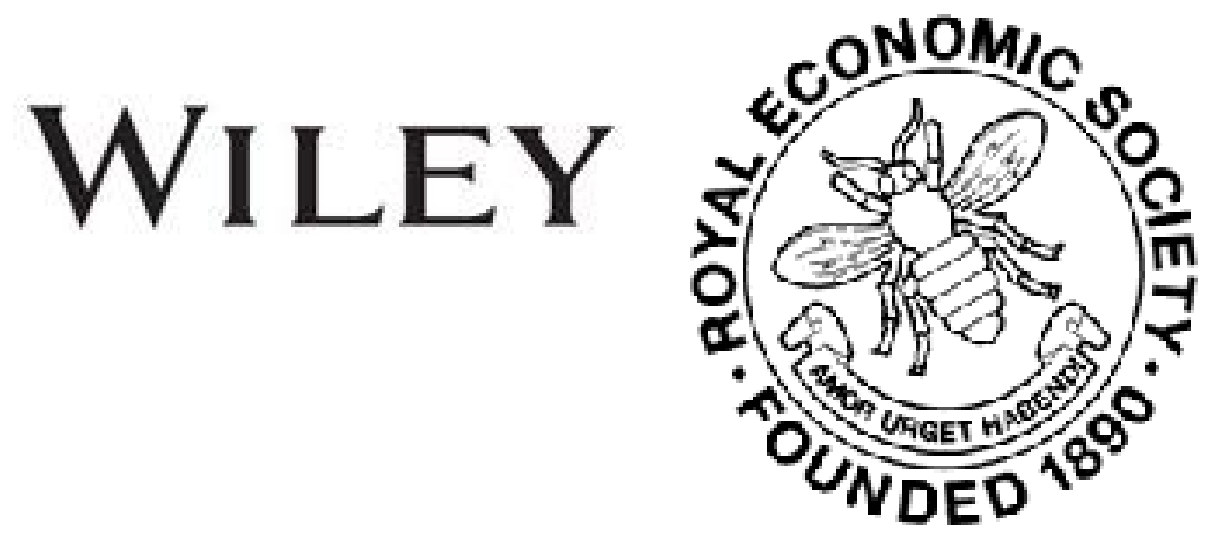

The National Agricultural Conference

Author(s): L. L. Price

Source: The Economic Journal, Vol. 3, No. 9 (Mar., 1893), pp. 128-134

Published by: Wiley on behalf of the Royal Economic Society

Stable URL: http://www.jstor.org/stable/2956059

Accessed: 26-06-2016 01:16 UTC

Your use of the JSTOR archive indicates your acceptance of the Terms \& Conditions of Use, available at

http://about.jstor.org/terms

JSTOR is a not-for-profit service that helps scholars, researchers, and students discover, use, and build upon a wide range of content in a trusted digital archive. We use information technology and tools to increase productivity and facilitate new forms of scholarship. For more information about JSTOR, please contact support@jstor.org.

Wiley, Royal Economic Society are collaborating with JSTOR to digitize, preserve and extend access to The Economic Journal 
previously stated have brought me is that the cotton industry of this country is too securely founded, and too well sustained, to admit of the idea of its permanent decadence. Wages disputes when they ripen into actual conflict tend no doubt to drive away, at least for a time, a portion of our trade. But wages disputes are transient incidents. So far as more lasting conditions are concerned, we shall probably have to wait some time for the advent of Free Trade abroad, and although this will assuredly bring into play new competition, there is no reason why we should fear it. Meanwhile our trade with foreign countries is being conducted with difficulty. Profits are usually small, and where they are not cut down merchants have to content themselves with a scanty trade. New outlets are being sought for in many directions, and much hope is centred in Africa. The improvement of the older markets presents, however, a large field for renewed effort, and, if the success of the Democratic party in the United States Presidential Election should prove the forerunner, as I believe it will, of the downfall of High Protectionism in the United States and elsewhere, there will be an ample field, by and by, in which our cotton manufactures may find, even among the older peoplesand without eventual injury to competing producers there--a fuller and freer market. The permanent utility to mankind of cotton manufactures is unquestionable, and no one who is engaged in the English home trade and who knows how greatly low prices enlarge consumption can doubt that even in the most advanced nations abroad an abundant demand for increased and greatly varied production would follow every movement in the direction of Free Trade. Cotton goods are still much too dear in many countries, and if they could be obtained more easily than is now possible, the demand for them would be indefinitely increased.

EliJah Helm

\section{The National Agricultural Conference}

On Wednesday and Thursday, the 7th and 8th of December last, St. James's Hall, London, was the scene of an assembly described by the Times as the "largest and most representative gathering of every interest connected with the cultivation of the land that has probably ever been brought together in this country.' The Conference was convened by the Central and Associated Chambers of Agriculture, and the Chairman of that body, Mr. James Lowther, presided over the deliberations. The object of the meeting, as he observed in his opening remarks, was to enable 'full expression to be given to the views of the agricultural community at the present grave crisis in their affairs.' 
The representative character of the attendance, and the sincerity of the views put forward, admit of as little doubt as the seriousness of the situation which occasioned the meeting. Whether some of the opinions, which aroused the most evident enthusiasm, and some of the resolutions, passed with the fewest dissentient voices, in St. James' Hall, are likely to meet with the approval, or, at any rate, with the warm and active support, of a wider public has been questioned, or denied, by the most influential organs of the London and provincial press; but it can scarcely be disputed that they express the firm convictions of a majority of the landowners and farmers present at the meeting, and it is hardly less certain that these two classes of the agricultural community were adequately represented in numbers and influence, though more doubt may be felt, and has been shown in not a few quarters, whether the representation of the labourer was equally sufficient or his representatives accorded so prominent and patient a hearing. Certainly one speaker, who claimed an acquaintance with the views of the labourers in a district of England, based on intimate intercourse, met with determined opposition in his attempts to induce the Conference to listen to what the majority regarded as unpalatable views. No reasonable suspicion, however, can be thrown on the adequacy of the representation of the other two classes. Some 240 bodies in alleither farmers' associations and clubs or labourers' unions-sent delegates, and so extensive and urgent had been the demand for tickets that the hall originally selected as the place of meetingthe Farringdon Street Conference Hall-had been found to afford inadequate accommodation, and the promoters of the Conference had accordingly secured in its stead the more ample dimensions of St. James' Hall. Even then numerous applications for admission were of necessity refused; and during the proceedings of the first of the two days, on which the Conference met, the hall was filled in every part by an interested audience which listened to the discussions with sustained attention for some half-dozen hours. The Times, in its report, estimated that upwards of 2000 noblemen and gentlemen were present, 'either as delegates or as occupying distinguished positions in the world of agriculture, as well as peers and members of Parliament of both the great political parties.' Mr. Chaplin, the Minister of the newly-formed Department of Agriculture in the late Conservative Government, moved the first resolution, and the chief newspapers gave full reports of the proceedings and devoted leading articles to the discussion of the various subjects raised. Of the significance, therefore, of the Conference as an expression of the mind of the landowning and occupying classes little doubt can reasonably be felt.

Nor has the gravity of the present agricultural position been seriously questioned in any important quarter. The disastrous harvests, which occurred in 1892 in many parts of the country, following on the indifferent results of the previous year, have fallen with overwhelming pressure on many landlords and farmers, whose resources

No. 9.-VOL. III 
for meeting such emergencies had been seriously crippled by the great decline in agricultural prices since the depression set in upwards of twenty years ago. For a while, indeed, as Mr. Chaplin observed in his review of the situation, there had been an arrest in that decline, and some two years ago the opinion was widely entertained in agricultural circles that matters had at last 'touched bottom.' There had even been a temporary recovery in prices; but the season of 1892 has witnessed, in addition to a further drop in the price of wheat to a figure unprecedentedly low, a serious fall in the price of stock. No doubt this latter result has been partly due to the lamentable deficiency of the hay harvest in many districts, and, with better crops of grass, and the opportunely abundant supply of roots, prices may recover; but the encroachments made on the income of the farmer by continued depression have been so large that he has, it seems, lost much of his old recuperative power, and the removal of the resource upon which he had fallen back-and hitherto with success-when wheat proved unremunerative, has reduced him to yery serious straits. On all sides the year 1892 has been compared with the disastrous year of 1879 , in which the results of depression first became decidedly manifest, and careful and competent observers are found to declare that the latter year is even worse than the earlier. The landlord, on his part, with a disposition to help his tenants, which was generally acknowledged at the Conference to prevail-at any rate with few exceptions-and has been shown in actual fact by the numerous notices of remissions appearing in the newspapers, finds his means of affording large temporary relief in peculiarly disastrous years sadly curtailed by the diminished rental which depression has brought with it. In some places the great house has been shut up, in others the improvement of buildings, and the execution of drainage and other works, have been arrested, and in others, again, the land has actually passed out of cultivation. Of the reality of the agricultural distress there can be no reasonable doubt; and it was under these circumstances that a National Conference was suggested to 'direct public attention to the present grave condition of agricultural affairs, to ventilate the grievances under which agriculture labours, and to consider suggestions for their removal.'

The proceedings of the first day, as the reports and the comments of the newspapers prove, excited the greater interest and attracted the larger audience. Some indeed of those who have criticised most severely, from different points of view, the conclusions at which the Conference then arrived, agree in declaring that the proceedings of the second day were of more practical importance, though they select for approval or disapproval, according as they are led by political or other predilections, different points in those proceedings. But they are none the less compelled to admit that the resolutions of the first day, however visionary and impracticable, commanded the enthusiastic adherence of a large majority of the audience. And, of the two sub- 
jects which were then raised-protection and bimetallism-there can be no doubt, whether the result be attributed to the more abstruse and difficult character of the latter, or to the more familiar and traditional aspect of the former, that the resolution in favour of protection expressed the real feelings and the genuine purpose which had brought together very many of those present. Although the resolution in favour of bimetallism was endorsed by the Conference as a whole, the attendance thinned during its discussion, and the significance of the other resolution is certainly not diminished by the fact that it was carried after Mr. Chaplin had emphatically declared it hopeless to expect that such a resolution would find favour with the general body of the electorate. On the next day, when the Conference proceeded to discuss the question of the rating of land, the conditions of tenure, the combination of farmers to dispense with the middleman and deal directly with the consumer, and the prevention of adulteration, and of the spread of tuberculosis, the attendance of the general public was, by comparison with that on the first day, of a meagre character, and the debates, with the exception of that on the conditions of land tenure, were far less animated.

The Conference opened with a brief speech from the Chairman, explanatory of its scope and arrangements, in which, with an evident suspicion, as it would seem to those who have since studied the proceedings, of what was coming, he expressed a hope that members would not be afraid of stating their own opinions. He did not, he added, ' speak of personal fads, but he hoped no one would hesitate to give full expression to what was believed by him to be the opinion of large sections of the agricultural community.' He then called upon Mr. Chaplin to move the first resolution, which directed attention to the critical condition of agriculture and to the urgent need of finding means of arresting the evil. Mr. Chaplin commenced his speech by quoting from Sir James Caird's evidence before the Depression of Trade Commission figures illustrative of the extent and consequences of the agricultural depression. These figures were submitted in 1886, and, as Mr. Chaplin remarked, that year marked neither the beginning nor the end of the depression. As early as 1879 the Duke of Richmond had presided over a Royal Commission specially appointed to inquire into the state of agriculture; and, Mr. Chaplin said, 'from that time till now we have been going steadily from bad to worse.' Sir James Caird's figures showed that ' on a rental of $£ 65,000,000$ the landlords had lost $£ 20,000,000$ or 30 per cent. of their income; the tenants had lost $£ 20,000,000$ or 60 per cent. of their income; the labourers $£ 2,800,000$ or 10 per cent. of their spendable income, making a total loss to the landed interest of spendable income amounting to no less than $\$ 42,800,000$.' Such was the result of depression in 1886, and since then the ' mischief has been steadily increasing.' In illustration Mr. Chaplin alluded to some figures furnished by the well-known agriculturist, Mr. Clay, to which the newspapers had given prominent

$\mathrm{K} 2$ 
publicity a few days before the Conference. Mr. Clay estimated that in 1891, as compared with twenty years before, there was a loss of upwards of 77 millions in the annual value of our agricultural produce. Nor was there, Mr. Chaplin added, any certainty that even now matters had 'touched bottom.' Wheat had fallen in price to a figure low beyond any precedent, but it might fall lower yet. And wheat did not stand alone in this respect. "The same thing is occurring with regard to cattle, sheep and wool, and almost every agricultural product that you can name.' 'It is,' Mr. Chaplin proceeded to remark, 'that great fall in prices which is the one remarkable and the one new feature in the present agricultural situation as compared with our prosperity in former days.' And hence he did not himself put faith in any remedies which left prices unaffected, excellent as they might be in their own proper place. Of the remedies directly connected with prices three had been suggested. One was a reduction of rent, the second was protection, and the third bimetallism. Dealing with the first Mr. Chaplin held that it had already been applied to a large extent, and that, where it had not, it was as certainly inevitable as it was also undoubtedly the most speedy and effective method of immediate relief. Some figures published in the Daily Telegraph, relating to Lord Leicester's estate at Holkham, in Norfolk, showed that the present rental yielded no more than a bare return of $2 \frac{1}{2}$ per cent. on the money expended on improvements, and this case was typical of a large number of others throughout the country. With an average reduction of rent of £1 an acre, what, Mr. Chaplin asked, must have happened to land which was only worth a pound or less before the depression commenced? Then came the question of foreign competition, and of a return to protection. The mention of this at an earlier stage in Mr. Chaplin's address had awakened manifest enthusiasm, and it was now again greeted with loud and continued cheering. But, Mr. Chaplin asked, had such a policy any chance of adoption? 'I should be,' he said, 'simply deceiving the members of this Conference if I were to conceal from you my own opinion and my strong conviction that in the present temper of the constituencies of the country any proposals for protection which included a duty upon food would meet, I am afraid, with certain and assured defeat.' Of bimetallism he entertained more confident hopes, and to cynical observers of politics the spectacle, which the Conference presented, of Mr. Chaplin expressing his approval on this subject of the views of Archbishop Walsh must seem somewhat amusing. But to serious thinkers the concurrence of public men so prominent in their respective spheres of influence must certainly appear likely to improve the chances of adoption of the reform they favour. "You have it in your power, if you will,' Mr. Chaplin observed, 'to command a majority for this policy.' ' $I$ do not think that it is quixotic on my part to assume that the ultimate decision of this question very largely depends upon the agricultural party in this country.'

The resolution moved by Mr. Chaplin was seconded. by Mr. Row- 
landson, who called attention to the ominous fact that cultivated land was deteriorating year by year owing to depression, and it was supported by Lord Winchilsea, who presented in outline an idea of forming an Agricultural Union of landlords, tenants and labourers, for joint action in important matters affecting landed interests, which he afterwards developed at greater length in a letter to the newspapers. An amendment, which excited no little disapproval, was then moved by Mr. Saunders to the effect that the fall in prices was the 'natural result of improved methods of production'; and the noisy, impatient reception accorded to this amendment, and to Mr. Saunders' remarks, formed a significant prelude to the discussion, which followed, on foreign competition. Here the feeling of the Conference, despite of opposition raised in influential quarters, was unmistakable, and a resolution was passed which was avowedly protectionist. The next resolution in favour of bimetallism was supported by Mr. Chaplin, and carried by a large majority, and the Conference adjourned to the following day. On this day the first subject on the programme dealt with the burden of taxation on landed property, and was introduced by Sir Richard Paget. His contention was that land had been diminishing in value during the last ten years, while other forms of property had been as steadily increasing, and that this circumstance called for readjustment of the burden of taxation. The next item on the programme referred to conditions of tenure, and the first resolution moved was one in favour of an absolute right to the value of unexhausted improvements, of the abolition of the law of distress, and of the equal division of local rates between owners and occupiers. In the course of the discussion it appeared that so competent and experienced an agriculturist as Mr. Clare Sewell Read was distinctly of opinion that the Agricultural Holdings Act required amendment; but the most important incident of the debate was undoubtedly the introduction of an amendment, advocating the establishment in England of the principles known as the three Fs. This amendment was moved by a representative of the Lancashire farmers, who had originally suggested the meeting of the Conference, and on the previous day had strenuously objected to the resolution passed in favour of protection as a "red herring" drawn across the track. The gravamen of their complaint lay against the landlord, but the discussion aroused by their amendment seemed to show that, with the exception of certain districts or particular individuals, the relations between landlords and tenants were of a friendly character, and that the former had generally recognised the obligations which the bad times laid upon them in the matter of fair reductions of rent. Mr. Chaplin spoke emphatically against the amendment, which was rejected, and the original resolution put to the meeting. The right of the tenant to unexhausted improvements was asserted with but few dissentient voices, but the abolition of the law of distress was only carried by a small majority. This discussion, like that of the previous day on protection, revealed a difference 
between the position and opinions of the farmers of the north and south. The former had as yet, it seemed, suffered less from depression, and their rents had not undergone such reductions. They did not wish to have recourse to the desperate expedient of protection; but, on the other hand, the relations between themselves and their landlords were more estranged. After this exciting topic the Conference settled down to the quiet discussion of co-operation among farmers, and adulteration, and tuberculosis and swine-fever, and, with the passing of a cordial vote to the Chairman, the meeting terminated. Whether the practical outcome will or will not be disappointing, has been widely discussed, but the public is at any rate placed in possession of the views of prominent agriculturists, and the proposal put forward by Lord Winchilsea of an Agricultural Union has been actively taken up in various districts, and may exercise no inconsiderable influence upon the future course of politics. At all events, as the Chairman remarked, the Conference is likely to be memorable in agricultural history, if only as marking a period of extreme depression.

L. L. Price

\section{The New Railway Rates.}

' Every careful student of the question, from Morrison in 1836 down to the Committees of 1873 and 1882, has come to the conclusion that fixed maxima are of next to no use in preventing extortion.' So wrote Professor Hadley in 1885. Unfortunately, however, the British public and the British Parliament have no confidence in careful students, and prefer to look for guidance to the practical man, being apparently under the impression that each person who feels his shoe pinch him becomes ipso facto a fully qualified shoe-maker. The practical man's prescription for the disease of excessive railway rates was a revision of statutory maxima; a revision of statutory maxima has accordingly been carried through, at an expense of certainly not less than $£ 500,000$; with what result may be read in the daily papers. Of the "lamentable and ludicrous fiasco' of this attempt at railway legislation there is no need to speak. And this for two reasons; in the first place no one yet knows what has really happened, whether rates on the whole are higher or lower than they were; in the second place 'every careful student of the question ' must have foreseen that the public would hear of the increases and be told nothing of the reductions, and will therefore have been fully prepared for the outcry which has actually been raised. For my own part, having on three separate occasions in the last two years published a forecast of the present position, ${ }^{1}$ now that the events have actually occurred I do not find it necessary to add or to alter a single

1 The Railways and the Traders. London: John Murray, February 1891. Nineteenth Century, January and December, 1892. 